Anders Jidesjö has a teacher education in science and technology for secondary school and a master degree in science. He is working at the University of Linköping in Sweden at the research department of water and environmental studies. He is one of the graduate students in the Swedish national graduate school in science and technology education research (FontD) and has carried out the ROSE study in Sweden.

\title{
Different content orientations in science and technology among primary and secondary boys and girls in Sweden: Implications for the transition from primary to secondary school?
}

\begin{abstract}
This paper presents Swedish results from the Relevance of Science Education (ROSE) study, which is part of a large world-wide comparative research study based at the University of Oslo. The national sample was collected in spring 2003 and originates from 751 students from 29 schools, most of whom were 15 years old. In an additional study data from primary students were collected in spring 2005, with a smaller sample of 112. Significant differences in content orientation between the primary and secondary boys and girls were found and are discussed in the context of young people's interest in science and technology and the public function of those knowledge fields as a part of education. Earlier studies suggest the benefit of more applicative contexts as the children move through compulsory school. This statement is challenged to some degree in this paper and a stronger need to understand how the transition from primary to secondary level and specific contents are related is discussed. This is due to indications that students' content orientations are partially dependant on age and there are significant differences due to gender to consider. A deeper examination of those elements can assist in the understanding of the relevance of science from the learners' perspectives.
\end{abstract}

\section{INTRODUCTION}

The data provided in this paper deals with what students in primary and secondary science classrooms want to learn about. The empirical studies were carried out in Sweden at year five, with mostly 11 year olds and at year nine, with mostly 15 year olds. The latter is part of a large worldwide research project, the Relevance of science Education study (ROSE), under the direction of Professor Svein Sjøberg, University of Oslo. The smaller study, with primary students, has been carried out in Sweden only. All details concerning ROSE, including background, rationale, underlying ideas, data collection and methodological issues can be found in Schreiner and Sjøberg (2004).

To make young people appreciate science instruction and take part with a sense of participation is a main goal in compulsory school and is also stressed in an early review of students' attitudes to science by Gardner (1975). Since then a lot of research has been carried out investigating the affective domain in science education with a drop in publications during the 1990s. However, attention has now been once again focused on this field of research (Ramsden, 1998). Today many different 
actors take an active part in the discussion of future generations' interest in science and technology and in many countries it receives more and more attention (Jenkins, 2000). How to treat science content in school has been debated for a long time and there are different opinions about the selection of content and type of teaching (see for example Duschl, 2000; Fensham, 1988, 2000). Today much of this debate is about scientific literacy, concerning aims, definitions and practice (Bybee, 1997). It has been suggested by Roberts (2007), that scientific literacy as an educational slogan is best understood when concentrating on two visions: Vision 1 concentrates on educating people into the world of science, understanding societal concerns as a scientist would. However, vision 2 is a citizens understanding of the importance of science for modern life, a comprehension of the ways scientific results are arrived at, are interpreted and permeate societal structures. In society experts in science and technology are needed, but also a population with a good general level of education where these knowledge fields constitute essential parts, i.e. science and technology as essential parts of education. Some will work in the world of science and technology; others will deal with science-based social concerns (DeBoer, 2000). Millar (2006) reports on the '21st century science' project developed in England, implementing scientific literacy in school science. Millar calls the tension between the two visions 'pre-professional training for some' and 'scientific literacy for all' and analyses ways they can coexist and what this means for the selection of content and teaching skills. Most people are consumers of scientific knowledge, not producers. Therefore, the aim is to take advantage of young people's interests and deal with them in a fashion more attuned to everyday experiences of the subjects. However, student opinions have been marginalized in both educational research and curriculum development. For the most part, learners have been regarded as receivers of teaching, unable to decide what they should learn. This means that during their period of training, they are not regarded as having equal rights when fundamental decisions are made (Jenkins \& Nelson, 2005). A new situation is at hand. The learners are consumers of scientific knowledge often experienced through media. Different actors are active in the exposure of scientific knowledge and the content is treated in various contexts from a variety of standpoints. For those reasons, the learners' perspective, which means a student centred approach, is important to consider when debating a reconceptualisation of science education (Osborne, 2007; Sjøberg, 2007).

Investigations of students' attitudes to science point to gender differences as an important variable. Already Gardner (1975) argued that boys are more interested in physical sciences while girls are more oriented to Biology and Health. Many studies confirm this picture and in general girls seem to be more negative to school science (Greenfield, 1997; Kelly, 1986; Mattern \& Schau, 2002; Murphy \& Beggs, 2003; Reid \& Skryabina, 2003). Some studies also point to gender variations as being content dependent. It is not only a question of science as a broad knowledge field or different subjects, but the content is also experienced by children in different ways and these experiences change because of societal development (Jones, Howe \& Rua, 2000; Sjøberg, 2000). The current ROSE study is a further elaboration in this direction. Schreiner (2006) reports on international ROSE data and describes five distinct student types, with different orientations towards science, seen as signs of late modern identities. She also shows that gender differences become stronger the more modernized a country becomes, which has consequences for what subject matter young people want to learn about. Another important variable to consider is temporal. Many studies have found that children's interest in science is a downward trend with increasing age (see for example George, 2000; Greenfield, 1997; Pell \& Jarvis, 2001; Murphy \& Beggs, 2003). Children seem to have greatest interest in the content when they are in primary school, but when they are asked later in life what they want to learn, physical sciences often come out at the bottom (Spall, Stanisstreet, Dickson \& Boyes, 2004; Angell, Guttersrud, Henriksen \& Isnes, 2004). Baram-Tsabari \& Yarden (2005) investigated children's spontaneous interests and found that with increasing age, children shifted from biology to technology and astrophysics with an internal shift in biology from zoology to human biology. Physics was found to be more interesting among younger children. They also show a shift in interest from non-applicative to applicative questions. Consequently, both gender differences and age seems to be to some extent content dependant, which means there 
is a question of understanding progression in science education. Lindahl (2003) partly confirms this picture. She showed that Swedish students' interests in Physics and Chemistry are low and decrease as the children move from primary to secondary level while for other subjects it is higher and increases.

Progression from primary to secondary level is one challenge for science education (Braund \& Driver, 2005) and relating this transition to content is essential. Several researchers point to the need to understand this better, see for example Davies and McMahon (2004) and also Chapman (2001). Both these studies present some concrete remedial measures, pointing to the need for joint planning, co-operation and communication between schools. Meeting places between schools and science departments are also pointed out. The need for out of school experiences is also stressed by Braund and Reiss (2006), arguing that more authentic science experiences are needed because of societal development. Jarvis and Pell (2002) investigated the effect on elementary children's attitudes to science of having gained such a concrete experience at a learning centre. The overall message is that it is possible to develop children's learning of science if the visits are carefully prepared by the teachers. This is to say, other learning environments exposing science content in ways that will attract people (see Davidsson \& Jakobsson, 2007), have developed in society which can constitute resources for teachers. Perhaps because of this, young people have never before been in contact with science based issues as much as they are today. Teachers in primary schools want science activities that work with their children, i.e. hands-on activities that are motivating and interesting for the children with a clear outcome and result, using equipment that is available and manageable in the classroom and integrating science into themes (Appleton, 2002). Almost analogous inferences are made by Littledyke (2004) pointing out that children at an early age have an interest in learning science based on their experiences but that it is more difficult for them to relate the content to impacts on society or the environment. What is brought up and how it is treated in different sections during the compulsory period of training is challenging and needs further attention. Braund \& Driver (2005) put together some of the research evidence on those matters, pointing out that: students at secondary level repeat work done at primary school without advances in challenge; in the transition the learning culture changes because teachers styles are very different and it is hard for the students to adjust; previous learning experiences are seldom noticed and many teachers at secondary level distrust the levels students have been assessed at in primary schools which is sometimes used as an argument to start from the beginning. At the same time, students have high expectations for secondary science schooling involving the use of more sophisticated equipment and dangerous chemicals, more challenging work and practical science exercises as a method for learning (Braund \& Driver, 2005). To bridge this discontinuity with the introduction of inquiry-based projects and the establishment of an agenda for school science more attuned to the needs of children, seems hard (Brown \& Melear, 2005). Bridging work however, has been done. The results point to high satisfaction among the students and the importance of teacher collaboration and carefully prepared teaching materials (Braund \& Hames, 2005). Also, both primary and secondary teachers appreciated the bridging work, however, no strong differences concerning the students performance was measured (Braund, 2007). Students' attitudes to science are greatly influenced by 'teacher variables' (Osborne, Simon \& Collins, 2003) and underlying beliefs about teaching and learning are the most important factors that need to be reflected on to establish a student centred practice (Bencze, Bowen \& Alsop, 2006; Trumbull, Scarano \& Bonney, 2006). One way to progress further is to become learner sensitive and to ask the learners what they find important or difficult (Maskill \& Pedrosa de Jesus, 1997; van Zee, Iwasyk, Kurose, Simpson \& Wild, 2001; Watts, Alsop, Gould \& Walsh, 1997). This means that the learners are very important actors for developing school science instruction.

Although science and technology are clear parts of primary schooling, surprisingly little research that pays attention to young children's perspectives has been carried out (Pell \& Jarvis, 2001). There is research evidence that points out gender differences, age, teacher variables and out of school experiences as key elements for children's perceived relevance of science content. Few 
investigations have looked at contents in themselves, which means that when discussing young peoples' interests few connections to specific content are made. Instead broad categories are often used, such as 'science' or different subjects. A student-centred view, rather than an adult subject oriented view, on the relevance of science education can deliver important messages more attuned to the needs of the learners. The studies reported in this paper compare what content students in primary with what content students in secondary education want to learn about in science and are analysed from the following research question:

- What are the differences in content orientations in science and technology between students in primary and secondary education?

\section{THE SWEDISH SCIENCE CURRICULUM FOR COMPULSORY SCHOOL}

Swedish science syllabuses divide into three different subjects: Biology, Chemistry and Physics. In addition, there is a general science syllabus. Technology has its own syllabus but in many schools technology is taught together with science. There is a revised version of the science curriculum for compulsory schools from the year 2000. The schools' mission is formulated in terms of three objectives and capabilities, i.e. "concerning nature and Man", "concerning scientific activity" and "concerning use of knowledge". Teachers are free when it comes to type of teaching and content arrangement. The wording depicts science as a process developed through human activity, a way of describing and making our surroundings intelligible, an important part of our cultural heritage and stresses the need for sustainable development (the National Swedish Agency for Education, 2008).

\section{THE SAMPLE}

In ROSE a questionnaire is used divided into several categories. In this paper data from the category "What I want to learn about" are presented. The students in grade five have answered only to this one where there are 108 items concerning astrophysics, earth science, human biology with sex and reproduction, genetics, zoology, botany, chemistry, optics, acoustics, electricity, energy, technology, Science, Technology and Society (STS) and Nature Of Science (NOS). The questions are put in different contexts such as spectacular phenomena, fear, technological ideas and inventions, aesthetical aspects, beauty, care, health, personal use and everyday relevance.

The data from primary schools were collected in grade five, in five classes from three schools, in two different municipalities in the south of Sweden, in a province called Östergötland. A small pilot study with ten students in another class was carried out to see if there were any problems in understanding the items. It took them about 20 minutes to complete and no uncertainty was noticed. A test-assistant visited each school and gave information about the project, distributed the questionnaires and collected them. Nothing problematical was reported regarding data collection from a total of 112 students in spring 2005. The data constitute 53 girls and 59 boys, 19 ten year olds, 78 eleven and 15 twelve year olds.

The data from secondary schools is a national sample and part of the international ROSE data set. In 2003 the student cohort aged 15 in Sweden (ninth and last year in the Swedish compulsory school system) comprised about 110000 individuals distributed over 1577 schools. From these, 30 schools were randomly selected out of a sample with nine stratum variables to assure correct weight for each type of school. The schools themselves selected one class. The size of the classes varied from 20 to 35 students with the exception of one class with 15 students. A test assistant visited each school. This person gave information about the project, distributed the questionnaires and later collected them. Nothing problematical was reported regarding data collection from a total of 751 students from 29 schools. 


\section{RESULTS}

Table 1 presents the first ten items with highest means respectively primary and secondary students want to learn about.

Table 1. Comparison between what primary and secondary students want to learn about in science and technology. The ten items with highest means in a falling order with standard deviations (SD). Common items in italic.

\begin{tabular}{|l|l|l|l|}
\hline Statements primary students & $\begin{array}{l}\text { Mean } \\
\text { (SD) }\end{array}$ & Statements secondary students & $\begin{array}{l}\text { Mean } \\
\text { (SD) }\end{array}$ \\
\hline $\begin{array}{l}\text { Why we dream while we are } \\
\text { sleeping, and what the dreams may } \\
\text { mean }\end{array}$ & $\begin{array}{l}2.9 \\
(1.0)\end{array}$ & $\begin{array}{l}\text { How to exercise to keep the body fit } \\
\text { and strong }\end{array}$ & $\begin{array}{l}3.0 \\
(1.0)\end{array}$ \\
\hline $\begin{array}{l}\text { How it feels to be weightless in } \\
\text { space }\end{array}$ & $\begin{array}{l}2.9 \\
(1.0)\end{array}$ & How it feels to be weightless in space & $\begin{array}{l}3.0 \\
(1.0)\end{array}$ \\
\hline Animals in other parts of the world & $\begin{array}{l}2.8 \\
(1.0)\end{array}$ & The possibility of life outside earth & $\begin{array}{l}2.9 \\
(1.0)\end{array}$ \\
\hline $\begin{array}{l}\text { How to exercise to keep the body fit } \\
\text { and strong }\end{array}$ & $\begin{array}{l}2.8 \\
(1.0)\end{array}$ & $\begin{array}{l}\text { Why we dream while we are } \\
\text { sleeping, and what the dreams may }\end{array}$ & $\begin{array}{l}2.9 \\
\text { mean }\end{array}$ \\
\hline $\begin{array}{l}\text { How cassette tapes, CDs and DVDs } \\
\text { store and play sound and music }\end{array}$ & $\begin{array}{l}2.8 \\
(0.9)\end{array}$ & $\begin{array}{l}\text { How different narcotics affect the } \\
\text { body }\end{array}$ & $\begin{array}{l}2.8 \\
(1.0)\end{array}$ \\
\hline How computers work & 2.7 & $\begin{array}{l}\text { How alcohol and tobacco affects the } \\
\text { body }\end{array}$ & $\begin{array}{l}2.8 \\
(1.0)\end{array}$ \\
\hline $\begin{array}{l}\text { Brutal, dangerous and threatening } \\
\text { animals }\end{array}$ & $\begin{array}{l}2.7 \\
(1.0)\end{array}$ & What to eat to keep healthy and fit & $\begin{array}{l}2.8 \\
(1.0)\end{array}$ \\
\hline $\begin{array}{l}\text { The possibility of life outside earth } \\
(1.0)\end{array}$ & $\begin{array}{l}\text { What we know about HIVIAIDS and } \\
\text { how to control it }\end{array}$ & $\begin{array}{l}2.8 \\
(1.0)\end{array}$ \\
\hline $\begin{array}{l}\text { Dinosaurs, how they lived and why } \\
\text { they died out }\end{array}$ & $\begin{array}{l}2.7 \\
(0.9)\end{array}$ & $\begin{array}{l}\text { How to perform first-aid and use } \\
\text { basic medical equipment }\end{array}$ & $\begin{array}{l}2.8 \\
(1.0)\end{array}$ \\
\hline How the atom bomb functions & $\begin{array}{l}2.7 \\
(1.0)\end{array}$ & $\begin{array}{l}\text { Phenomena that scientists cannot } \\
\text { explain }\end{array}$ & $\begin{array}{l}2.8 \\
(1.0)\end{array}$ \\
\hline
\end{tabular}

The two groups of students have four items in common: dreams and what they mean, how to keep the body fit and strong, weightlessness in space and the possibility of life outside earth. Primary students put forward animals in the world, dinosaurs and dangerous and threatening animals together with modern technology as computers, CD, DVD and the atom bomb. In late secondary education items like narcotics, alcohol and tobacco, diet, health and phenomena that scientists cannot explain are at the top of the list. Also, some of the wording that primary students put forward, i.e. 'store and play', 'work', 'how they lived', 'why they died' and 'functions' are noteworthy. Compare these with some of the wording that comes up with students in secondary education, i.e. 'affect the body', healthy and fit', 'what we know' and 'cannot explain'. There are some indications that primary students are more oriented towards how things work, the functions and explanations that lie behind them and towards areas like zoology and technology while secondary students are more oriented towards complex issues like effects on the body of things you eat, health, what we know about modern diseases and things that scientists cannot explain. 
As there are significant differences the next step in this analysis is to look more in detail both at the girls' and the boys' differences. In Table 2, a comparison between what primary and secondary girls want to learn about is presented.

Table 2. Comparison between what primary and secondary girls want to learn about in science and technology. The ten items with highest means in a falling order with standard deviations (SD). Common items in italic.

\begin{tabular}{|l|l|l|l|}
\hline Statements primary girls & $\begin{array}{l}\text { Mean } \\
\text { (SD) }\end{array}$ & Statements secondary girls & $\begin{array}{l}\text { Mean } \\
\text { (SD) }\end{array}$ \\
\hline Animals in other parts of the world & $\begin{array}{l}3.2 \\
(1.0)\end{array}$ & $\begin{array}{l}\text { Why we dream while we are } \\
\text { sleeping, and what the dreams may } \\
\text { mean }\end{array}$ & $\begin{array}{l}3.4 \\
(0.9)\end{array}$ \\
\hline $\begin{array}{l}\text { Why we dream while we are } \\
\text { sleeping, and what the dreams } \\
\text { may mean }\end{array}$ & $\begin{array}{l}3.2 \\
(1.0)\end{array}$ & $\begin{array}{l}\text { How to exercise to keep the body fit } \\
\text { and strong }\end{array}$ & $\begin{array}{l}3.2 \\
(0.8)\end{array}$ \\
\hline $\begin{array}{l}\text { How it feels to be weightless in } \\
\text { space }\end{array}$ & $\begin{array}{l}3.0 \\
(1.0)\end{array}$ & $\begin{array}{l}\text { What we know about HIV/AIDS and } \\
\text { how to control it }\end{array}$ & $\begin{array}{l}3.2 \\
(0.9)\end{array}$ \\
\hline $\begin{array}{l}\text { How to exercise to keep the body } \\
\text { fit and strong }\end{array}$ & $\begin{array}{l}2.9 \\
(1.0)\end{array}$ & $\begin{array}{l}\text { How different narcotics might affect } \\
\text { the body }\end{array}$ & $\begin{array}{l}3.1 \\
(0.8)\end{array}$ \\
\hline $\begin{array}{l}\text { Brutal, dangerous and threatening } \\
\text { animals }\end{array}$ & $\begin{array}{l}2.9 \\
(1.0)\end{array}$ & What to eat to keep healthy and fit & $\begin{array}{l}3.1 \\
(0.9)\end{array}$ \\
\hline $\begin{array}{l}\text { Dinosaurs, how they lived and why } \\
\text { they died out }\end{array}$ & $\begin{array}{l}2.8 \\
(1.0)\end{array}$ & $\begin{array}{l}\text { How alcohol and tobacco might } \\
\text { affect the body }\end{array}$ & $\begin{array}{l}3.1 \\
(0.8)\end{array}$ \\
\hline The possibility of life outside earth & $\begin{array}{l}2.8 \\
(1.0)\end{array}$ & $\begin{array}{l}\text { How to perform first-aid and use } \\
\text { basic medical equipment }\end{array}$ & $\begin{array}{l}3.1 \\
(0.9)\end{array}$ \\
\hline Animals in my area & $\begin{array}{l}2.8 \\
(1.0)\end{array}$ & $\begin{array}{l}\text { Sexually transmitted diseases and } \\
\text { how to protect against them. }\end{array}$ & $\begin{array}{l}3.1 \\
(0.9)\end{array}$ \\
\hline $\begin{array}{l}\text { How the eye can see light and } \\
\text { colours }\end{array}$ & $\begin{array}{l}2.8 \\
(1.0)\end{array}$ & $\begin{array}{l}\text { Cancer, what we know and how we } \\
\text { can treat it }\end{array}$ & $\begin{array}{l}3.1 \\
(0.9)\end{array}$ \\
\hline What to eat to keep healthy and fit & $\begin{array}{l}2.7 \\
(1.0)\end{array}$ & $\begin{array}{l}\text { Thought transference, mind-reading, } \\
\text { sixth sense, intuition, etc. }\end{array}$ & $\begin{array}{l}3.1 \\
(1.0)\end{array}$ \\
\hline
\end{tabular}

Already among these ten items, only three are common to both groups indicating that there are interesting differences. Looking at the items primary girls put forward, 'animals in other parts of the world' is on top. 'Brutal, dangerous and threatening animals' together with dinosaurs and 'animals in my area' are not far behind. Weightlessness in space and the possibility of life outside earth are also popular items among primary girls and there is an item concerning how the eye can see light and colours. Focussing on the secondary girls', items like HIV/AIDS, narcotics, alcohol, tobacco, first-aid, sexually transmitted diseases, and cancer are at the top. Telepathy, mind-reading, sixth sense and intuition are also highly rated as interesting to learn about. The next step is to look at the boys in the same manner. 
Table 3. Comparison between what primary and secondary boys want to learn about in science and technology. The ten items with highest means in a falling order with standard deviations (SD). Common items in italic.

\begin{tabular}{|c|c|c|c|}
\hline Statements primary boys & $\begin{array}{l}\text { Mean } \\
\text { (SD) }\end{array}$ & Statements secondary boys & $\begin{array}{l}\text { Mean } \\
\text { (SD) }\end{array}$ \\
\hline How the atom bomb functions & $\begin{array}{l}3.3 \\
(1.0)\end{array}$ & How it feels to be weightless in space & $\begin{array}{l}3.1 \\
(1.0)\end{array}$ \\
\hline Explosive chemicals & $\begin{array}{l}3.0 \\
(1.0)\end{array}$ & How the atom bomb functions & $\begin{array}{l}3.0 \\
(1.0)\end{array}$ \\
\hline $\begin{array}{l}\text { The use of lasers for technical } \\
\text { purposes (CD-players, bar-code } \\
\text { readers, etc.) }\end{array}$ & $\begin{array}{l}2.9 \\
(1.0)\end{array}$ & Explosive chemicals & $\begin{array}{l}3.0 \\
(1.0)\end{array}$ \\
\hline $\begin{array}{l}\text { How cassette tapes, CDs and } \\
\text { DVDs store and play sound and } \\
\text { music }\end{array}$ & $\begin{array}{l}2.9 \\
(1.0)\end{array}$ & How computers work & $\begin{array}{l}3.0 \\
(1.0)\end{array}$ \\
\hline How computers work & $\begin{array}{l}2.9 \\
(0.9)\end{array}$ & The possibility of life outside earth & $\begin{array}{l}2.9 \\
(1.0)\end{array}$ \\
\hline $\begin{array}{l}\text { Biological and chemical weapons } \\
\text { and what they do to the human } \\
\text { body }\end{array}$ & $\begin{array}{l}2.8 \\
(1.0)\end{array}$ & $\begin{array}{l}\text { Biological and chemical weapons and } \\
\text { what they do to the human body }\end{array}$ & $\begin{array}{l}2.9 \\
(1.0)\end{array}$ \\
\hline $\begin{array}{l}\text { The origin and evolution of life on } \\
\text { earth }\end{array}$ & $\begin{array}{l}2.7 \\
(1.0)\end{array}$ & $\begin{array}{l}\text { How to exercise to keep the body fit } \\
\text { and strong }\end{array}$ & $\begin{array}{l}2.9 \\
(1.0)\end{array}$ \\
\hline $\begin{array}{l}\text { How it feels to be weightless in } \\
\text { space }\end{array}$ & $\begin{array}{l}2.7 \\
(1.0)\end{array}$ & $\begin{array}{l}\text { Phenomena that scientists still cannot } \\
\text { explain }\end{array}$ & $\begin{array}{l}2.8 \\
(1.1)\end{array}$ \\
\hline Cloning of animals & $\begin{array}{l}2.7 \\
(1.0)\end{array}$ & $\begin{array}{l}\text { How meteors, comets or asteroids } \\
\text { may cause disasters on earth }\end{array}$ & $\begin{array}{l}2.8 \\
(1.0)\end{array}$ \\
\hline The possibility of life outside earth & $\begin{array}{l}2.6 \\
(1.0)\end{array}$ & $\begin{array}{l}\text { Black holes, supernovas and other } \\
\text { spectacular objects in outer space }\end{array}$ & $\begin{array}{l}2.8 \\
(1.1)\end{array}$ \\
\hline
\end{tabular}

Among the boys, six of the items are common to both age groups already in the first ten out of 108 , which is twice as much when compared with the girls. The common items are about the atom bomb, explosive chemicals, biological and chemical weapons, computers, weightlessness in space and the possibility of life outside earth. The four items among only primary boys are the use of laser for technical purposes, how CDs and DVDs functions, cloning of animals and the origin and evolution of life on earth. Comparing with the secondary boys, health issues with the human body and contemporary challenges facing society comes up.

When looking at the other end of this list, items that students do not want to learn about are varied. 
Table 4. Comparison between what primary and secondary students do not want to learn about in science and technology. The ten items with lowest means in a falling order with standard deviations (SD). Common items in italic.

\begin{tabular}{|l|l|l|l|}
\hline Statements primary students & $\begin{array}{l}\text { Mean } \\
\text { (SD) }\end{array}$ & Statements secondary students & $\begin{array}{l}\text { Mean } \\
\text { (SD) }\end{array}$ \\
\hline $\begin{array}{l}\text { How crude oil is converted to other } \\
\text { materials, like plastics and textiles }\end{array}$ & $\begin{array}{l}1.8 \\
(0.9)\end{array}$ & $\begin{array}{l}\text { How mountains, rivers and oceans } \\
\text { develop and change }\end{array}$ & $\begin{array}{l}1.9 \\
(0.8)\end{array}$ \\
\hline $\begin{array}{l}\text { Why religion and science some- } \\
\text { times are in conflict }\end{array}$ & $\begin{array}{l}1.8 \\
(0.9)\end{array}$ & $\begin{array}{l}\text { How technology helps us to handle } \\
\text { waste, garbage and sewage }\end{array}$ & $\begin{array}{l}1.9 \\
(0.9)\end{array}$ \\
\hline $\begin{array}{l}\text { How scientific ideas sometimes } \\
\text { challenge religion, authority and } \\
\text { tradition }\end{array}$ & $\begin{array}{l}1.8 \\
(0.9)\end{array}$ & Why scientists sometimes disagree & $\begin{array}{l}1.9 \\
(0.9)\end{array}$ \\
\hline $\begin{array}{l}\text { Why scientists sometimes disagree } \\
(0.9)\end{array}$ & $\begin{array}{l}\text { Benefits and possible hazards of } \\
\text { modern methods of farming }\end{array}$ & $\begin{array}{l}1.9 \\
(0.9)\end{array}$ \\
\hline $\begin{array}{l}\text { Alternative therapies (acupuncture, } \\
\text { homeopathy, yoga, healing, etc.) } \\
\text { and how effective they are }\end{array}$ & $\begin{array}{l}1.8 \\
(0.9)\end{array}$ & Plants in my area & $\begin{array}{l}1.8 \\
(0.8)\end{array}$ \\
\hline $\begin{array}{l}\text { How to improve the harvest in } \\
\text { gardens and farms }\end{array}$ & $\begin{array}{l}1.7 \\
(0.9)\end{array}$ & $\begin{array}{l}\text { Detergents, soaps and how they } \\
\text { work }\end{array}$ & $\begin{array}{l}1.8 \\
(0.8)\end{array}$ \\
\hline $\begin{array}{l}\text { Benefits and possible hazards of } \\
\text { modern methods of farming }\end{array}$ & $\begin{array}{l}1.7 \\
(0.9)\end{array}$ & How plants grow and reproduce & $\begin{array}{l}1.8 \\
(0.8)\end{array}$ \\
\hline $\begin{array}{l}\text { How technology helps us to handle } \\
\text { waste, garbage and sewage }\end{array}$ & $\begin{array}{l}1.7 \\
(1.0)\end{array}$ & Famous scientists and their lives & $\begin{array}{l}1.7 \\
(0.8)\end{array}$ \\
\hline $\begin{array}{l}\text { Symmetries and patterns in leaves } \\
\text { and flowers }\end{array}$ & $\begin{array}{l}1.6 \\
(1.0)\end{array}$ & $\begin{array}{l}\text { How crude oil is converted to other } \\
\text { materials, like plastics and textiles }\end{array}$ & $\begin{array}{l}1.6 \\
(0.8)\end{array}$ \\
\hline $\begin{array}{l}\text { Organic and ecological farming } \\
\text { without use of pesticides and } \\
\text { artificial fertilizers }\end{array}$ & $\begin{array}{l}1.6 \\
(0.9)\end{array}$ & $\begin{array}{l}\text { Symmetries and patterns in leaves } \\
\text { and flowers }\end{array}$ & $\begin{array}{l}1.4 \\
(0.7)\end{array}$ \\
\hline
\end{tabular}

Five of the items are in common. Primary students are negative towards 'why religion and science sometimes are in conflict', 'how scientific ideas sometimes challenge religion and tradition', 'alternative therapies', 'how to improve harvests' together with 'organic and ecological farming'. Actually, some of these items are important contemporary issues in a modern society but primary students give them low attention. In addition to the commonalities, secondary students are negative towards 'how mountains and rivers develop and change', plants in the local surrounding, 'how plants grow and reproduce', 'how detergents work' and 'famous scientists and their lives'. In fact, several of these items are concerned with how things in the close surroundings work, i.e. local experiences of science and technology. As seen earlier some of these 'how things work' items are popular among the primary students.

The last step in this analysis is to look more in detail at the shifts between what primary and secondary boys and girls do not want to learn about. 
Table 5. Comparison between what primary and secondary girls do not want to learn about in science and technology. The ten items with lowest means in a falling order with standard deviations (SD). Common items in italic.

\begin{tabular}{|c|c|c|c|}
\hline Statements primary girls & $\begin{array}{l}\text { Mean } \\
\text { (SD) }\end{array}$ & Statements secondary girls & $\begin{array}{l}\text { Mean } \\
\text { (SD) }\end{array}$ \\
\hline $\begin{array}{l}\text { How to improve the harvest in gardens } \\
\text { and farms }\end{array}$ & $\begin{array}{l}1.8 \\
(0.9)\end{array}$ & How plants grow and reproduce & $\begin{array}{l}1.8 \\
(0.8)\end{array}$ \\
\hline $\begin{array}{l}\text { Alternative therapies (acupuncture, } \\
\text { homeopathy, yoga, healing, etc.) and } \\
\text { how effective they are }\end{array}$ & $\begin{array}{l}1.8 \\
(1.0)\end{array}$ & $\begin{array}{l}\text { Benefits and possible hazards of } \\
\text { modern methods of farming }\end{array}$ & $\begin{array}{l}1.8 \\
(0.9)\end{array}$ \\
\hline How petrol and diesel engines work & $\begin{array}{l}1.8 \\
(0.9)\end{array}$ & $\begin{array}{l}\text { How to use and repair everyday } \\
\text { electrical and mechanical } \\
\text { equipment }\end{array}$ & $\begin{array}{l}1.8 \\
(0.9)\end{array}$ \\
\hline $\begin{array}{l}\text { How crude oil is converted to other } \\
\text { materials, like plastics and textiles }\end{array}$ & $\begin{array}{l}1.7 \\
(0.9)\end{array}$ & $\begin{array}{l}\text { Electricity, how it is produced and } \\
\text { used in the home }\end{array}$ & $\begin{array}{l}1.8 \\
(0.8)\end{array}$ \\
\hline Why scientists sometimes disagree & $\begin{array}{l}1.7 \\
(0.9)\end{array}$ & $\begin{array}{l}\text { How technology helps us to } \\
\text { handle waste, garbage and } \\
\text { sewage }\end{array}$ & $\begin{array}{l}1.8 \\
(0.8)\end{array}$ \\
\hline Birth control and contraception & $\begin{array}{l}1.7 \\
(0.9)\end{array}$ & $\begin{array}{l}\text { How a nuclear power plant } \\
\text { functions }\end{array}$ & $\begin{array}{l}1.8 \\
(0.9)\end{array}$ \\
\hline How a nuclear power plant functions & $\begin{array}{l}1.6 \\
(0.9)\end{array}$ & $\begin{array}{l}\text { How petrol and diesel engines } \\
\text { work }\end{array}$ & $\begin{array}{l}1.7 \\
(0.8)\end{array}$ \\
\hline $\begin{array}{l}\text { Benefits and possible hazards of } \\
\text { modern methods of farming }\end{array}$ & $\begin{array}{l}1.6 \\
(0.9)\end{array}$ & Famous scientists and their lives & $\begin{array}{l}1.6 \\
(0.8)\end{array}$ \\
\hline $\begin{array}{l}\text { How technology helps us to handle } \\
\text { waste, garbage and sewage }\end{array}$ & $\begin{array}{l}1.5 \\
(0.8)\end{array}$ & $\begin{array}{l}\text { Symmetries and patterns in leaves } \\
\text { and flowers }\end{array}$ & $\begin{array}{l}1.5 \\
(0.8)\end{array}$ \\
\hline $\begin{array}{l}\text { Organic and ecological farming without } \\
\text { use of pesticides and artificial fertilizers }\end{array}$ & $\begin{array}{l}1.5 \\
(0.8)\end{array}$ & $\begin{array}{l}\text { How crude oil is converted to } \\
\text { other materials, like plastics and } \\
\text { textiles }\end{array}$ & $\begin{array}{l}1.5 \\
(0.7)\end{array}$ \\
\hline
\end{tabular}

Five of the items are in common. Among the primary girls there is a lack of interest in 'how to improve harvests' and 'organic and ecological farming' together with 'why scientists sometimes disagree'. An unscientific context comes up as the least interesting, i.e. 'alternative therapies and how effective they are'. It is also worth noting that birth control and contraception are among the least interesting, if primary girls in this study make the choice. In addition to the commonalities, secondary girls are uninterested 'how plants grow and reproduce', 'how to repair everyday electrical and mechanical equipment' and 'how electricity is produced and used'. 'Famous scientists' and 'symmetries and patterns in leaves and flowers' are also among the least interesting where the secondary girls are concerned. 
Table 6. Comparison between what primary and secondary boys do not want to learn about in science and technology. The ten items with lowest means in a falling order with standard deviations (SD). Common items in italic.

\begin{tabular}{|l|l|l|l|}
\hline Statements primary boys & $\begin{array}{l}\text { Mean } \\
\text { (SD) }\end{array}$ & $\begin{array}{l}\text { Statements secondary } \\
\text { boys }\end{array}$ & $\begin{array}{l}\text { Mean } \\
\text { (SD) }\end{array}$ \\
\hline $\begin{array}{l}\text { The ozone layer and how it } \\
\text { may be affected by humans }\end{array}$ & $\begin{array}{l}1.8 \\
(0.9)\end{array}$ & $\begin{array}{l}\text { Plastic surgery and cosmetic } \\
\text { surgery }\end{array}$ & $\begin{array}{l}1.8 \\
(0.9)\end{array}$ \\
\hline $\begin{array}{l}\text { Big blunders and mistakes in } \\
\text { research and inventions }\end{array}$ & $\begin{array}{l}1.8 \\
(0.9)\end{array}$ & $\begin{array}{l}\text { Alternative therapies } \\
\text { (acupuncture, homeopathy, } \\
\text { yoga, healing, etc.) and how } \\
\text { effective they are }\end{array}$ & $\begin{array}{l}1.8 \\
(0.9)\end{array}$ \\
\hline $\begin{array}{l}\text { Famous scientists and their } \\
\text { lives }\end{array}$ & $\begin{array}{l}1.8 \\
(0.9)\end{array}$ & $\begin{array}{l}\text { How plants grow and } \\
\text { reproduce }\end{array}$ & $\begin{array}{l}1.8 \\
(0.8)\end{array}$ \\
\hline $\begin{array}{l}\text { The greenhouse effect and } \\
\text { how it may be changed by } \\
\text { humans }\end{array}$ & $\begin{array}{l}1.7 \\
(0.9)\end{array}$ & Plants in my area & $\begin{array}{l}1.8 \\
(0.8)\end{array}$ \\
\hline $\begin{array}{l}\text { Why religion and science } \\
\text { sometimes are in conflict }\end{array}$ & $\begin{array}{l}1.7 \\
(0.8)\end{array}$ & $\begin{array}{l}\text { Famous scientists and their } \\
\text { lives }\end{array}$ & $\begin{array}{l}1.7 \\
(0.9)\end{array}$ \\
\hline $\begin{array}{l}\text { The ability of lotions and } \\
\text { creams to keep the skin } \\
\text { young }\end{array}$ & $\begin{array}{l}1.7 \\
(0.8)\end{array}$ & $\begin{array}{l}\text { Eating disorders like } \\
\text { anorexia or bulimia }\end{array}$ & $\begin{array}{l}1.7 \\
(0.8)\end{array}$ \\
\hline $\begin{array}{l}\text { How scientific ideas } \\
\text { sometimes challenge } \\
\text { religion, authority and } \\
\text { tradition }\end{array}$ & $\begin{array}{l}1.7 \\
(0.8)\end{array}$ & $\begin{array}{l}\text { Detergents, soaps and how } \\
\text { they work }\end{array}$ & $\begin{array}{l}1.7 \\
(0.8)\end{array}$ \\
\hline $\begin{array}{l}\text { Organic and ecological } \\
\text { farming without use of } \\
\text { pesticides and artificial } \\
\text { fertilizers }\end{array}$ & $\begin{array}{l}1.7 \\
(0.8)\end{array}$ & $\begin{array}{l}\text { How crude oil is converted to } \\
\text { other materials, like plastics } \\
\text { and textiles }\end{array}$ & $\begin{array}{l}1.7 \\
(0.8)\end{array}$ \\
\hline $\begin{array}{l}\text { How to improve the harvest } \\
\text { in gardens and farms }\end{array}$ & $\begin{array}{l}1.7 \\
(0.8)\end{array}$ & $\begin{array}{l}\text { The ability of lotions and } \\
\text { creams to keep the skin } \\
\text { young }\end{array}$ & $\begin{array}{l}1.6 \\
(0.8)\end{array}$ \\
\hline $\begin{array}{l}\text { Symmetries and patterns in } \\
\text { leaves and flowers }\end{array}$ & $\begin{array}{l}1.5 \\
(0.7)\end{array}$ & $\begin{array}{l}\text { Symmetries and patterns in } \\
\text { leaves and flowers }\end{array}$ & $\begin{array}{l}1.3 \\
(0.6)\end{array}$ \\
\hline
\end{tabular}

Only three items are in common between the primary and secondary boys. Primary boys exhibit a lack of interest in items like the ozone layer and the greenhouse effect together with big blunders and mistakes in research and inventions. Why religion and science sometimes are in conflict and how scientific ideas sometimes challenge religion and authority are also at the bottom of the list together with organic and ecological farming and how to improve the harvest in gardens 
and farms. It is more common for the primary boys to have a lack of interest in societal matters when compared with the primary girls. Turning to the secondary boys, plastic surgery, alternative therapies and how effective they are (common with primary girls), local plants and their ecology, eating disorders, detergents and how crude oil is converted to other materials are all at the bottom of the list.

\section{Discussion}

Young people have an interest in science and technology both at primary and secondary level, but there are interesting differences in content orientation between the two age groups. Consequently, debates about the dislike for these knowledge fields among future generations are not in line with research evidence (see also Appleton, 2002; Braund \& Driver, 2005; George, 2000; Greenfield, 1997; Lindahl, 2003; Littledyke, 2004; Murphy \& Beggs, 2003; Schreiner, 2006). Pell and Jarvis (2001) found that students in primary education have enthusiasm for taking part in science exercises, especially practical investigations, but the source of joy fades away as they gradually move towards secondary education. This indicates a strong need to understand primary science education in relation to secondary schooling. It seems as though there is something related to science content in schools that phases out the enthusiasm among many students with an increasing power correlated with age. Since the review of Gardner (1975) these problems have been well known in the research community. Nevertheless, Ramsden (1998) called the situation 'mission impossible' and pointed to the need to carry out more research into the affective domain in science education, even though terms like 'interest' and 'attitude' are slippery and many researchers avoid grappling with them. Anyhow, in the primary phase students are full of expectations about their secondary science education, consisting of the use of more advanced equipment, dangerous chemicals, deeper practical studies and challenging work (Braund \& Driver, 2005). The results in this study confirm these but are also complementary. Indeed, the secondary students put forward more complex issues like diet and health, things researchers cannot explain and especially among the boys, the use of dangerous chemicals which calls for the use of more advanced equipment. There are also indications that primary students are more oriented to how things work, how animals lived, why they died and how things function. There is no need for any firm inferences about this as the sample is small and there is little research evidence about these kinds of differences. In a more extensive study it would be possible to use more advanced statistics to see if the things indicated here still apply. Yet, the secondary students are more oriented towards other statements such as 'how things affect', 'keeping healthy and fit', 'what we know about' and 'cannot explain'. The question of if these findings indicate that primary students are more satisfied with basic explanations about how things work and secondary students want contexts aiming more at wondering, challenging work and controversial contemporary issues needs more research. In the ambition of trying to understand primary science education in relation to secondary, there seem to be questions about both the contents themselves, a 'what question', and the ways that the content is treated, a 'how question'. There are already among the ten items among 108, see Table 1, indications that the content orientation shifts from basic zoology to human biology, from basic technology to more challenging issues dealing with cause and effects. Similar findings have been reported from BaramTsabari \& Yarden (2005) using a different methodology in a different culture. What the influence of the contents in themselves and the way they are treated have for young people's willingness to participate in science with joy and fulfilment needs further investigation.

The data in this study allows making comparisons between the sexes and delving deeper into the differences. Looking at the girls there are several items concerning animals, both locally and globally, dangerous, threatening and also extinct ones. These items do not appear at all among the secondary girls where health issues are more prominent. A shift from basic zoology to human biology in the context of medical sciences is evident among the girls. Additionally, the items of space among primary girls do not appear in the secondary group. Only three items are in common 
already among the first ten, indicating that there are significant shifts among girls. There is also one statement concerning 'how the eye can see light and colours'. This is only one example, but in relation to the background presented in this paper it is worth paying attention to. It appears as though this kind of question is more in line with students in late primary education. If the girls in secondary science classes make the choices, other questions would be asked much more concerned with relations between what we eat, diets and drugs, and consequences of that, what we know about modern diseases like cancer and HIV/AIDS, how to be protected from sexually transmitted diseases and maybe also some issues of telepathy, mind-reading and intuition. When looking at these results, a 'starting from scratch approach' in secondary science education would be devastating for the girls perceived relevance, discussed also by Braund and Driver (2005), Davies and McMahon (2004), Galton (2002; 2000) and Pointon (2000). The contribution from this study is the more detailed analysis of specific contents. When the differences among the sexes were further developed in the international ROSE study (Schreiner, 2006) the consistency among the girls and boys in the whole western world suggest that it is rather cultural factors that lie behind this than the use of different pedagogies.

Looking at the boys another interesting content orientation stands out. Firstly, six of the items among the first ten are in common between the primary and secondary boys, which are twice as many as among the girls, maybe indicating that the boys are more consistent. But again, as with the girls, primary boys put forward items which call for concrete explanations about how things work like 'the use of lasers for technical purposes', 'how cassette tapes, CDs and DVDs store and play sound and music', 'the origin and evolution of life on earth' and 'cloning of animals'. Those are the four items that do not appear among the secondary boys. Instead, how to exercise to keep fit, phenomena scientists cannot explain and space issues come up. However, many of the items are retained over the transition from primary to secondary level (see Table 3). The shift identified by Baram-Tsabari and Yarden (2005) from biology to technology is prominent when the boys and girls are analysed together. When the results are separated another pattern becomes clear. Namely, that the boys' interest in technology and space is fairly consistent. What seems to change is that also among the boys, interest in exercising to keep fit and strong, i.e. health issues and things we cannot explain, which are more challenging tasks develop. It must also be added that a shift from non-applicative to applicative items, also stressed by George (2000) as important to understand students' perceived relevance as they move through compulsory schooling, is somewhat challenged in this paper, but is also dependent on what is meant by applicative. George uses 'utility of science' and found strong correlation with students' attitudes towards science over the middle school years. Maybe this is confirmed in this study if that comprises a shift from dinosaurs and brutal animals to cancer, HIV/AIDS, sexually transmitted diseases and how diet and drugs affects the body. The point with this paper is to put forward students' perspectives on what is relevant to learn and that rather means to become learner sensitive and to see what happens when placing their perspective of science content in the middle, as one important part of the curriculum. What is worth paying attention to are differences in content orientation related to age and that those are gender dependant. Maybe this is more a question about advancement in inquiry projects due to a shift in content orientation due to age and gender.

The ten items with the lowest means can be understood as what students do not want to learn about (Table 4). Five items are in common and the five that signify the primary students are interplays between science and religion, issues about farming, alternative therapies and how effective they are. Littledyke (2004) discusses that many students at an early age show enthusiasm for science content, but not for the impacts on society, more for the contents in themselves. The five items that characterize the secondary students are how mountains, rivers and oceans develop and change, local plants, detergents, soaps and how they work, how plants grow and reproduce together with famous scientists and their lives. Several of these items are everyday experiences but get poor attention from the students. Several can also be called applicative. Nevertheless, what can be called local issues like 'animals in my area' are preferred among primary students but 'plants in 
my area' and 'how soaps work' come up at the bottom of the list among secondary students. Again, are those kinds of content more in line with younger children? The last part in this paper looks more in detail at the differences between girls and boys on these matters.

Concerning the girls, an interesting result is that the same kind of item that comes up as most interesting to learn about among the secondary girls (mind-reading, sixth sense and intuition) appears at the bottom of the list among the primary girls (alternative therapies and how effective they are). This item also gets low attention among the secondary boys. If there is something important in this finding, it seems as though younger girls hold some of the same attitudes towards science content as more grown up boys. In addition, birth control and contraception is at the bottom of the list among primary girls at the same time as sexually transmitted diseases and how to be protected from them constitute part of the top ten items among secondary girls. Hence, there is an indication again of considerable shift in girls' content orientation. I have used 'content orientation' when talking about the results as a way of avoiding the trap of saying that it is exactly those contents that appear here that are those that should be taught. It is what they represent that is important to understand, but there is not much help from earlier studies in making inferences about precisely that. Besides the common items, secondary girls exhibit a lack of interest in Botany, electricity, how to handle waste and 'famous scientists'. If it is true that many teachers in secondary schools distrust their students' levels of attainment and have a 'starting from scratch approach' when the girls enter secondary science education (Braund \& Driver, 2005) many of these knowledge fields will be taught, for example Botany, Zoology (which is something they want to learn about when they are younger), electricity and basic Chemistry. It is not unlikely to believe that this will have serious consequences for their perceived relevance. The boys have a lot in common with the girls with regard to their bottom lists. Two very important societal matters 'the ozone layer' and 'the greenhouse effect' get the lowest attention if the primary boys make a selection, which is an indication, once again that contemporary challenges are not in line with younger children. Big blunders and mistakes is another item that young boys do not want to learn about. Perhaps surprisingly secondary boys have plastic and cosmetic surgery together with eating disorders on their list. I would call those 'applicative' or 'utilities of science' belonging to the faculty of medicine and clinical sciences, which is what the secondary girls have among their favourite contents. From the data presented in this paper there is some basis to claim that stronger relations to specific contents are needed when discussing different students' interest in science.

The study presented here is done from the recognition and respect of the difficulties for teachers to attain all students' perceived relevance when engaged with science education. The maintenance of an authentic science instruction to the students seems to be connected with increasingly demonstrating the contribution of science to society. Maybe, because of this, STS-approaches become more important in the later part of compulsory schooling. Together with that, there seems to be a shift in content orientation, which means it is not only a question of showing practical implications, but also to understand that the same content is perceived differently, according to age. As several studies, in various countries and with different methods, point in this direction it is an interesting trace to follow making the 'age-variable' more concrete and connected with contents, not with broader categories like school subjects or academic disciplines. Appleton (2002) reports that teachers in primary schools want science activities that work, which are hands-on activities, using available equipment and integrating science into themes. When the students enter secondary education, many teachers distrust their levels of attainments (see Braund \& Driver, 2005). Sometimes this apprehension is used as an argument for 'starting from scratch'. This implies that in the transition teacher styles often change, previous learning experiences are seldom noticed and work done at primary level is repeated. Braund \& Driver propose 'bridging work' as a way of smoothing out this discontinuity and when implementing it, really, the learners as well as primary and secondary science teachers appreciate it (Braund, 2007). Another interesting discussion from 'bridging work' is that maybe there is a point to some discontinuity. This is because students sometimes want the changeover to be distinct, on their way from childhood to adulthood. Braund (2007) discusses a 
compromise called 'planned discontinuity'. On account of the experiences with bridging work, instead of teaching blocks, it would be more suitable with well identified science tasks, taught in late primary education and recognized, built on and developed in early secondary education.

\section{CONCLUSIONS}

Young people have an interest in science and technology both at primary and secondary level and their interests seem to be partly gender dependant. It is not successful to talk about interest in broad knowledge fields like 'science' or different 'school subjects'. This is because some of the contents belonging to for example Biology are at the top of the list and other items belonging to this subject are at the bottom. Hence, there is a need for studies that relate to specific contents.

Age is an important variable to understand in the comprehension of young people's interest in science and technology. Many of the items that primary girls and boys put as interesting to learn about do not appear at all with students in secondary schooling. This I have called differences in content orientation on account of age. In the ambition to smooth the transition between primary and secondary level a notion of content orientations can be of value. This also means that the concept of 'students' attitudes towards' is as well as 'science' too broad a concept. Are we talking about primary or secondary students, boys or girls or maybe other important divisions not used in this paper?

Today scientific literacy is an educational slogan with the aim of understanding the main purpose of science and technology as part of compulsory education. This is done from the recognition that some people will continue doing science as professionals, but most people will work in other areas and encounter science and technology on a daily basis in their lives. This means that the majority will need to learn some science and technology for citizenship as these knowledge fields have developed to important parts of culture. A democratic society enlightens its citizens and encourages participation in public discussions on cultural matters, but what should the contents be and how should they be treated to achieve scientific literacy for all? When it comes to school science, the students are one important stakeholder among others but are often marginalized and regarded as receivers. Therefore, the learners' perspectives are worth paying attention to and maybe there are things to learn from listening to them and become learner sensitive. A 21st century science is one that can deal with both 'pre-professional training for some' and 'scientific literacy for all' and understand what this means for selection of contents. To learn from the learners and understand what it is they put forward as an agenda where thinking and doing science is fun with a sense of participation is a useful attitude. The alternative can be adults that continue to emphasize academic disciplines as the main organizers of school science and a future generation that apprehends it with alienation and a feeling of being an outsider.

\section{ACKNOWLEDGEMENTS}

I wish to thank the following: the students who completed the questionnaires; their schools and their teachers who made the necessary arrangements; colleagues in the Department of Teacher Education and School Development at the University of Oslo for cooperation and advice on a number of matters, and all other ROSE partners around the world, the Research Council of Norway, the Norwegian Ministry of Education, the University of Oslo and the National Centre for Science Education in Norway for their financial support of the ROSE project. 


\section{REFERENCES}

Angell, C., Guttersrud, Ø., Henriksen, E. K., \& Isnes, A. (2004). Physics: frightful, but fun. Pupils' and teachers' views of physics and physics teaching. Science Education, 88, 683-706.

Appleton, K. (2002). Science activities that work: perceptions of primary school teachers. Research in Science Education, 32, 393-410.

Baram-Tsabari, A., \& Yarden, A. (2005). Characterizing children's spontaneous interests in science and technology. International Journal of Science Education, 27, 803-826.

Bencze, J. L., Bowen, G. M., \& Alsop, S. (2006). Teachers' tendencies to promote student-led science projects: associations with their views about science. Science Education, 90, 400-419.

Braund, M. (2007). 'Bridging work' and its role in improving progression and continuity: an example from science education. British Educational Research Journal, 33, 905-926.

Braund, M., \& Driver, M. (2005). Pupils' perceptions of practical science in primary and secondary school: implications for improving progression and continuity of learning. Educational Research, 47, 77-91.

Braund, M., \& Hames, V. (2005). Improving progression and continuity from primary to secondary science: pupils' reactions to bridging work. International Journal of Science Education, 27, 781-801.

Braund, M., \& Reiss, M. (2006). Towards a more authentic science curriculum: the contribution of out-of-school learning. International Journal of Science Education, 28: 1373-1388.

Brown, S. L., \& Melear, C. T. (2005). Investigation of secondary science teachers' beliefs and practices after authentic inquiry-based experiences. Journal of Research in Science Teaching, 43, 938-962.

Bybee, R. W. (1997). Achieving scientific literacy: from purposes to practices. Portsmouth, NH: Heinemann.

Chapman, S. (2001). Mind the gap! Building links between primary and secondary school science. Physics Education, 36, 218-221.

Davidsson, E., \& Jakobsson, A. (2007). Different images of science at Nordic science centres. International Journal of Science Education, 29, 1229-1244.

Davies, D., \& McMahon, K. (2004). A smooth trajectory: developing continuity and progression between primary and secondary science education through a jointly-planned projectiles project. International Journal of Science Education, 26, 1009-1021.

DeBoer, G. (2000). Scientific literacy: another look at its historical and contemporary meanings and its relationship to science education reform. Journal of Research in Science Teaching, 37, $582-601$.

Duschl, R. (2000). Making the nature of science explicit. In Millar, R., Leach, J., \& Osborne, J. (Eds.) Improving science education: the contribution of research (pp. 187-206). Buckingham: Open University Press.

Fensham, P. (1988). Familiar but different: some dilemmas and new directions in science education. In Fensham, P. (Eds.) Development and dilemmas in science education (pp. 1-26). Reprinted 2002, London: RoutledgeFalmer.

Fensham, P. (2000). Providing suitable content in the 'science for all' curriculum. In Millar, R., Leach, J., \& Osborne, J. (Eds.) Improving science education: the contribution of research (pp. 147-164). Buckingham: Open University Press.

Galton, M. (2002). Continuity and progression in science teaching at key stages 2 and 3. Cambridge Journal of Education, 32, 249-265.

Galton, M. (2000). School transfer and transition. International Journal of Educational Research, 33, 321-323.

Gardner, P. L. (1975). Attitudes to science: A review. Studies in Science Education, 2, 1-41.

George, R. (2000). Measuring change in students' attitudes toward science over time: An application of latent variable growth modeling. Journal of Science Education and Technology, 9, 213-225. 
Greenfield, T. A. (1997). Gender- and grade-Level differences in science interest and participation. Science Education, 81, 259-276.

Jarvis, T., \& Pell, A. (2002). Effect of the challenger experience on elementary children's attitudes to science. Journal of Research in Science Teaching, 39, 979-1000.

Jenkins, E. (2000). 'Science for all': time for a paradigm shift? In Millar, R., Leach, J., \& Osborne, J. (Eds.) Improving Science Education: The contribution of research (pp. 207-226). Buckingham: Open University Press.

Jenkins, E., \& Nelson, N. W. (2005). Important but not for me: students' attitudes towards secondary school science in England. Research in Science \& Technological Education, 23, 41-57.

Jones, M. G., Howe, A., \& Rua, M. J. (2000). Gender differences in students' experiences, interests, and attitudes toward science and scientists. Science Education, 84, 180-192.

Kelly, A. (1986). The development of girls' and boys' attitudes to science: A longitudinal study. International Journal of Science Education, 8, 399-412.

Lindahl, B. (2003). Lust att lära naturvetenskap och teknik? En longitudinell studie om vägen till gymnasiet. Dissertation (Göteborg studies in educational sciences 196), Göteborg, Acta Universitatis Gothoburgensis.

Littledyke, M. (2004). Primary children's views on science and environmental issues: examples of environmental cognitive and moral development. Environmental Education Research, 10, 217-235.

Maskill, M., \& Pedrosa de Jesus, H. (1997). Pupils' questions, alternative frameworks and the design of science teaching. International Journal of Science Education, 19, 781-799.

Mattern, N., \& Schau, C. (2002). Gender differences in science attitude-achievement relationships over time among white middle-school students. Journal of Research in Science Teaching, 39, 324-340.

Millar, R. (2006). Twenty first century science: insights from the design and implementation of a scientific literacy approach in school science. International Journal of Science Education, 28, 1499-1521.

Murphy, C., \& Beggs, J. (2003). Children's perceptions of school science. School Science Review, $84,109-116$.

Osborne, J. (2007). Engaging young people with science: thoughts about future direction of science education. In Linder, C., Östman, L., \& Wickman P-O. (eds) (2007). Promoting scientific literacy: science education research in transaction. Proceedings of the Linnaeus tercentenary symposium held at Uppsala University, Uppsala Sweden, May 28-29, 2007.

Osborne, J., Simon, S., \& Collins, S. (2003). Attitudes towards science: a review of the literature and its implications. International Journal of Science Education, 25, 1049-1079.

Pell, T., \& Jarvis, T. (2001). Developing attitude to science scales for use with children of ages from five to eleven years. International Journal of Science Education, 23, 847-862.

Pointon, P. (2000). Students' views of environments for learning from primary to secondary school. International Journal of Educational Research, 33, 375-382.

Ramsden, J. M. (1998). Mission impossible? Can anything be done about attitudes to science? International Journal of Science Education, 20, 125-137.

Reid, N., \& Skryabina, E. A. (2003). Gender and physics. International Journal of Science Education, 25, 509-536.

Roberts, D. A. (2007). Linné scientific literacy symposium. Opening remarks by Douglas A. Roberts. In Linder, C., Östman, L., \& Wickman P-O. (eds) (2007). Promoting scientific literacy: science education research in transaction. Proceedings of the Linnaeus tercentenary symposium held at Uppsala University, Uppsala Sweden, May 28-29, 2007.

Schreiner, C. (2006). Exploring a ROSE-garden: Norwegian youth's orientations towards science - seen as signs of late modern identities. Doctoral thesis, University of Oslo, Faculty of Education, Department of Teacher Education and School Development, Oslo. 


\section{Anders Jidesjö}

Schreiner, C., \& Sjøberg, S. (2004). Sowing the seeds of ROSE. Background, rationale, questionnaire development and data collection for ROSE (The Relevance of science Education) - a comparative study of students' views of science and science education. Oslo, Unipub AS.

Sjøberg, S. (2007). Challenges for science education. A personal view. In Linder, C., Östman, L., \& Wickman P-O. (eds) (2007). Promoting scientific literacy: science education research in transaction. Proceedings of the Linnaeus tercentenary symposium held at Uppsala University, Uppsala Sweden, May 28-29, 2007.

Sjøberg, S. (2000). Science and Scientists: the SAS study. Cross-cultural evidence and perspectives on pupils' interests, experiences and perceptions. Oslo, Department of Teacher Education and School Development.

Spall, K., Stanisstreet, M., Dickson, D., \& Boyes, E. (2004). Development of school students' constructions of biology and physics. International Journal of Science Education, 26, 787-803.

The National Swedish Agency for Education. (2008). Retrieved January 31, 2008, from the World Wide Web:

http://www3.skolverket.se/ki03/front.aspx?sprak=SV\&ar=0708\&infoty $p=23 \&$ skolform $=11 \& i d=$ 3878 \&extraId $=2087$

Trumbull, D. J., Scarano, G., \& Bonney, R. (2006). Relations among teachers' practices and beliefs, conceptualizations of the nature of science, and their implementation of student independent inquiry projects. International Journal of Science Education, 28, 1717-1750.

van Zee, E. H., Iwasyk, M., Kurose, A., Simpson, D., \& Wild, J. (2001). Student and teacher questioning during conversations about science. Journal of Research in Science Teaching, 38, 159-190.

Watts, M., Alsop, S., Gould, G., \& Walsh, A. (1997). Promoting teachers' constructive reflection: pupils' questions as critical incidents. International Journal of Science Education, 19, 10251037. 